\title{
Theory of the Firm and Integrated Reporting Model: First Essay from NIBR Guidelines for SMES in Italy
}

\author{
Maria-Gabriella Baldarelli ${ }^{1}$, Antonietta Cosentino ${ }^{2}$, Mara Del Baldo ${ }^{3} \&$ Angela Magistro $^{2}$ \\ ${ }^{1}$ Department of Management, Rimini Campus, University of Bologna, Italy \\ ${ }^{2}$ Department of Law and Economics of Productive Activities, University of Rome La Sapienza, Rome, Italy \\ ${ }^{3}$ Department of Economics, Society and Politics, University of Urbino Carlo Bo, Urbino, Italy \\ Correspondence: Maria Gabriella Baldarelli, Department of Management, Rimini Campus, University of \\ Bologna, Italy. E-mail: maria.baldarelli@unibo.it
}

Received: March 30, 2020

doi:10.5539/ijbm.v15n6p84
Accepted: April 25, 2020

Online Published: May 15, 2020

URL: https://doi.org/10.5539/ijbm.v15n6p84

\begin{abstract}
This paper investigates the theoretical relationships among Integrated Reporting (IR) and the theory of the firm. The review of the integrated reporting literature is focused on the Business Administration perspective. The paper aims to understand what is the possible innovations which can be grasped about the theory of the firm underpinning IR. A qualitative research is carried out on the basis of three different phases: the search for relevant key words, the content analysis applied to Network Italian Business Reporting (NIBR) Guidelines for SMEs in Italy, and finally an in-depth interview to an expert belonging to NIBR committee. The results show that the idea underpinning the integrated reporting (IR) seems to underline the value of other capitals rather than financial one that are considered only according to their contribution to the company's wealth. Nevertheless, the empirical research of this paper as well the most recent Business Administration literature review showed that despite all the premises the results are still quite disappointing. This paper contributes to both literature and practice by offering an in-depth analysis of the link between the theoretical aspects of business theory, the current evolutionary trends in accounting (expressed by IR) and their application in the real world. The results of this paper can offer interesting insights to scholars and accounting professional bodies who must lead accountability strategies and tools.
\end{abstract}

Keywords: theory of the firm, integrated reporting, business administration, NIBR Guidelines for SMEs

\section{Introduction}

The issue of some stimuli about new concept of the firm underpinning the integrated reporting is particularly relevant in the European context and in Italy. Following the transposition of the European directive (2014/95/EU), Italian Legislative decree 254/2016 requires listed companies, banks and insurance companies of certain size to draw up a non-financial statement, containing additional information on the environment, society, workforce, respect for human rights, active and passive anti-corruption measures. Non financial information have to disclose in addition to the traditional annual statements (La Torre, Sabelfeld, Blomkvist, Tarquinio, \& Dumay, 2018; Monciardini \& Conaldi, 2019; Campra, Esposito, \& Lombardi, 2020). One of the tools that companies can use to comply with legal requirements is integrated reporting (IR) on which there is an extensive literature (Flower, 2015; Brown \& Dillard, 2014; Rowbottom \& Locke, 2016).

This paper shifts away from the studies on the theory of the firm to verify whether a different theory of the firm emerges from new reporting method (Sorci, 2006; Paternostro, 2012; Pollifroni, 2017). Our approach adopts the point of view of Business Administration (Italian Economia aziendale). It follows that Accounting Theories and the Theories of the Firm on which the former are based, strictly following the Business Economics approach, influence not only the notion of what the firm is, with its objectives, its operations and its relationships with stakeholders, but also the appraisal of its results (financial and non-financial) as well as the representation of the latter in the reporting system.

In the field of company reporting the most recent streams of research propose a critical approach to the mainstream business theory and its vision of the firm. Indeed, the firm that emerges from these studies resembles a tool designed to produce wealth and development for the community as a whole, with an idea of the firm that is 
far beyond the assumptions both of the shareholder theory, and the stakeholder theory. In particular, IR above all in certain aspects (Eccles \& Krzus, 2010; Busco, Frigo, Quattrone, \& Riccaboni, 2013; Mio, 2016; Dumay \& Zambon, 2016); emerges as the product of a new and complex approach (Lai, 2004; Paternostro, 2012; Rusconi, $2019)$ to the study of firms, designed to portray their ability to create "global value". Knowledge of this complex and "integrated" value enables a better understanding of a company's future perspectives (Mouritsen, Bukh \& Marr, 2005) through a more complete and truthful disclosure (Veltri, Bronzetti, \& Sicoli, 2011; Dumay \& Zambon, 2016).

Indeed, despite widespread acknowledgement of the invaluable corpus of knowledge of the Business Administration in the field of the theory of the firm, the Economics approach had influenced the ways and aspects of corporate performance that have to be disclosed (Magistro, 1989; Ferraris Franceschi, 1998). This is essentially due to the reason that Business Administration, in its systemic vision of the firm (Amaduzzi, 1969), has accepted and incorporated the important contributions on the behaviour and strategies of firms offered by managerial theories formulated by Economists. In this way, not only has the area of study also where Economics and Business Administration meet widened, but shared survey methods are also increasingly used (Ferraris Franceschi, 1998; Baldarelli, Del Baldo, \& Vignini, 2019). Thus the work aims to answer to the research question:

"Could the theory of the firm, that is underlined by IR, open to innovation by way of the Business Administration perspective?"

To comply the paper aim an in-depth analysis of the link between the theoretical aspects of business theory, the current evolutionary trends in accounting (expressed by IR) and their application in the real world will be carried out. The findings show that the accounting framework designed for the SMEs, to draw up the IR, does not seem to make a real contribution to a new business theory.

This paper can contribute to existing studies through a careful evaluation of the contribution that the introduction both of new variables and a greater degree of complexity in the reporting system can bring knowledge of the operations of companies. The results of this paper can offer interesting insights to scholars and accounting professional bodies who must lead accountability strategies and tools.

The paper is structured as follows. Section 2 reviews the theoretical background to the main issues. Section 3 points out the research methodology and the results from empirical research. Finally, section 4 sets out the conclusions and implications, along with the limitations.

\section{Literature Review: Integrated Reporting and the Theory of the Firm in Dialogue}

\subsection{The Theory of the Firm "Underpinning" to Integrated Reporting}

The most recent streams of research in non-financial reporting, focusing attention on new tools to communicate the value creation process (such as the social report, the sustainability report, the intangible report and the integrated report), also take a different stance and lend themselves to a critique of mainstream theory, as the result of a new and complex approach to the study of companies (Lai, 2004; Paternostro, 2012; Pollifroni, 2017).

Since 2010, with the launch of the pilot programme by IIRC (International Integrated Reporting Council), the foundations of the development of the IR guiding principles have been laid (IIRC, 2013). The voluntary implementation of this reporting model, aimed at providing a "holistic" representation of financial and non-financial performance, has attracted the interest of the scientific, institutional and managerial worlds and fuelled a lively debate that impassions accounting scholars. This debate intensified with the introduction of the European Parliament directive (EU, 2014), transposed in Italy with Italian Legislative decree n. 254 of 30 December 2016 (La Torre et al., 2019; Dumay, La Torre \& Farneti, 2019) (Note 1).

The integrated reporting process presupposes a new management and governance approach summed up in the concept of integrated thinking (Dumay \& Dai, 2016). Alexander and Blum (2016), subscribing to drawing from the Complex Systems Theory approach, clearly state that the IIRC Framework is of little value in promoting sustainability and encouraging a theory of the firm that diverges from the traditional one (based on the neoclassical model), because of regulatory capture. They are convinced that a broader framework is needed in order to consider "the complex set of systems and sub-systems involved in the multi-capital, multi-measurement-unit, multi-stakeholder, and multi-motivated content of the sustainability issue" (Alexander \& Blum, 2016, p. 241).

Embracing the idea that each type of reporting is associated with a particular theory of the firm, in the rest of this section shall be considered the different perspectives adopted in literature in order to verify the existence (or lack) of links between the theoretical framework on which the integrated report is grounded and critical review of 
Accounting. The related academic literature does in fact draw on a number of frameworks (Speziale, 2018; Camilleri, 2018) and, principally, on the stakeholder theory, the institutional theory and the legitimacy theory, used to understand the institutional drivers of integrated reporting, company-level antecedents, the advantages/benefits and criticalities of implementation (De Villiers, Venter \& Hsiao, 2017; Dumay, Bernardi, Guthrie \& Demartini, 2016; Perego, Kennedy \& Whiteman, 2016; Velte \& Stawinoga, 2017).

Among the different theoretical approaches, Parker (2005) identifies two main groups of theories: "augmentation" and "heartland theories". The first group (Stakeholder theory, Economic Agency theories, Decision-usefulness theories, Legitimacy theory, Accountability theory) deals with non-financial reporting (including social and environmental accountability - SEA) as an addendum to conventional accounting. The second group focuses instead on the role of information in the relationships between the organisation and society (Political Economy Accounting Theory, Deep Green Ecological Perspectives, Eco-feminist Approach, Communitarian-based Theories).

The reflections presented below focus therefore on three of the most popular theories in order to identify the "missing links", starting from that which made it possible "to go beyond" the capitalistic theory of the firm (Shareholder Theory), seriously undermined by the global financial crisis, corporate scandals and a loss of faith in companies, which have been called upon to show greater responsibility and transparency and a more stakeholder-inclusive corporate governance approach.

The stakeholder approach (Freeman \& Reed, 1983; Freeman, 1984; Donaldson \& Preston, 1995; Freeman, Harrison, Wicks, Parmar \& De Colle, 2010) is in general the most widely used approach in studies that explain the development of non-financial and multidimensional reporting (social, environmental and integrated), which broadens the perspective within which corporate strategies are formulated to include all those who, in various capacities, have an interest in the corporate activity (Signori \& Rusconi, 2009; Rusconi, 2019; Pollifroni, 2012, 2017), prompting managers to provide greater disclosure on programmes and activities and to pursue a dialogue with stakeholders (Roberts, 1992) to meet their expectations (Deegan, 2002; Gray, Kouhy \& Lavers, 1995) and balance conflicting requirements (Chapman, Cooper \& Miller, 2009).

Donaldson and Preston (1995) identify three contrasting aspects in the use of the stakeholder theory, used to: describe and explain corporate characteristics and behaviour (descriptive stakeholder theory); explore the connections (or gaps) between stakeholder management and the achievement of objectives (instrumental stakeholder theory); or affirm that the interested parties must first of all be treated as people, whose rights must be respected - normative stakeholder theory (Evan \& Freeman, 1988). It follows that it is (only) in the latter of the three accepted meanings that the choice of integrated reporting rests on an "expanded", different conception of the firm, called upon to generate economic, but also social, environmental and ethical wealth, following moral guidelines for governance and administration.

In this regard, Flower's critique (2015) strikes us as relevant, as it underlines how the concept of integrated reporting set out in the IIRC Framework is based on the instrumental stakeholder theory, and therefore consistent with the capitalistic theory of the firm, which views interested parties as a mean to maximize shareholder value. In fact, it "uses stakeholder concerns and expectations" to increase profitability and market shares: in the event of any conflict of interest, the information needs of capital providers and investors take priority.

Flower $(2015$, p. 1) asserts that the IIRC has abandoned its "original" goal: "the IIRC's principal objective was the promotion of sustainability accounting, whereas later in the Framework the IIRC has abandoned this goal" and he traces the causes of this "decoupling"/abandonment to the IIRC governing council, an organism dominated by the accountancy profession and by multinational enterprises that seem determined to control initiatives with the potential to undermine the capitalistic theory of the firm and/or threaten/chip away at their established position in the field of corporate reporting. It is in such circumstances that the previously mentioned phenomenon of 'regulatory capture' emerges. Furthermore, while the aim of integrated reporting is to increase disclosure regarding the value creation process, the concept itself is open to several interpretations (Flower, 2015): it can be intended as "value to investors", "value to stakeholders", "value to society" and "value to present and future generations" (sustainability).

Although it lists six different types of capital, the IR Framework focuses predominantly on "value to investors", while the other capitals (for example, the quality of the workforce or the value of customer relations) are valued on the basis of their contribution to the firm's profit-making activities. Raising further criticism, Thomson (2015) argues that although integrated reporting and thinking may produce some positive social and environmental changes, they do not lead to any substantive redistribution of power (which remains economic and financial) with a consequent shift towards real sustainability. These assumptions are shared by Stubbs and Higgins (2015) 
who argue that precedence is given to creating financial value and furthering the interests of managers and practitioners, following a weak sustainability paradigm.

Tweedie and Martinov-Bennie (2015, p. 49) offer further reflections that cast a shadow over the chasm between the main body of theory that forms the basis of IR and a new vision of the firm. The scholars claim that the IR Framework is double-edged from a sustainability perspective, as it favours the following aspects: "(i) communication over holding organisations accountable; (ii) organisational over social sustainability and (iii) providers of financial capital over other stakeholders". Integrated reporting therefore concentrates on the information needs of capital providers (Brown \& Dillard, 2014) and does not guarantee corporate responsibility towards stakeholders (Rowbottom \& Locke, 2016; Adams, 2015; Van Bommel, 2014), nor does it incentivise a conscious capitalism model (Smith, 2016; Simpson, Fischer \& Rhode, 2013).

A partial response to such criticism comes from Haller and van Staden (2014) who identify the "value-added statement" as a tool for reporting the firm's ability to produce and distribute value to stakeholders and to contribute to the national economy (Maunders, 1985). In Italian Business Administration literature, the theoretical foundations of this proposal were laid by a female scholar, Gabrovec Mei (1984), one of the pioneers of social accounting (Baldarelli \& Del Baldo, 2018).

Lastly, it should be noted that studies which adopt the institutional theory (Jensen \& Berg 2012), sometimes used together with the stakeholder theory or the legitimacy theory. The first of these studies considers the choice of integrated reporting a function of multiple external factors (a country-level system, including the country's value system) and internal factors (or firm-specific factors, including ownership concentration, size, the level of corporate responsibility). Nevertheless, empirical research offers conflicting results, and the same applies to studies based on the Legitimacy Theory (Parker, 2005).

\subsection{The Theory of the Firm Following the Business Administration Italian Tradition: Some Notes}

Studies regarding 'theories of the firm', held dear by Business Administration, include important contributions that are continually reviewed and analysed, also at international level (Mattessich, 2013; Viganò, 2013). It is impossible here to list them all and, without any claim to exhaustiveness, this paper shall limit itself to mentioning those that are deemed most relevant for the purposes of this research, leaving more comprehensive studies to deal with the epistemological treatment of Italian Business Administration from Zappa until now.

In this subsection, the analysis starts from Gino Zappa, because he is the figure who, in Italy, must be credited with the founding statute of Business Administration in the shape of his renowned work "New trends in accounting studies" (1927). Despite the prevailing use of the English terms Business Economics or Business Administration as a translation for Italian label "Economia Aziendale", neither of the two fully conveys the meaning of the discipline founded by Gino Zappa, a problem tackled in philological and conceptual debate (Viganò, 2013; Canziani, 2013; Guarini, Magli \& Nobolo, 2013). This paper shall limit itself to referencing a few passages which seem useful for the purpose of this study.

Business Administration aims to study the "azienda" (firm / company / business / enterprise are the common words to translate the noun "azienda" in the international context and literature). The label "azienda" is a concept, an economic reality, a system of parts and people, operations and functions. It is different from firm or other terms such as company, corporation, undertaking. It includes both profit and non-profit organisations, and non-business and governmental entities (Viganò, 2013). Business Administration investigates the firm from an economic point of view, carried out from the internal perspective not from the market point of view like microeconomics (Capaldo, 2010). Viganò underlines that "It implies that all fields of study about the firm, such as accounting, management, organisations, marketing, finance, and so on, are strictly interconnected (...) They are considered simply as specializations within an autonomous science" (Viganò, 2013,p. 423).

Zappa proposes a so-called 'institutional' vision of the firm, conceived as an "economic institution destined to last" (Zappa, 1957). The firm is a system; it represented as an autonomous, real, and living organism that consist of elements, things and people, interact with one another (Viganò, 2013). Of great interest for the purpose of this study, is the scholar's thinking with regard to the objectives pursued by the firm, particular objectives which "must always be balanced and integrated by the necessary pursuit of greater goals embraced by the community within which the firm operates: these goals tend to describe themselves as pertaining to the common good (Zappa, 1962, p. 714).

Continuing this stream of study, in accordance with authoritative doctrine (Lai, 2004), it seems that Zappa has a multi-stakeholder vision of the firm when he views income as the firm's capacity to remunerate shareholder, and at the same time a 'summary' of all other remunerations which, in the form of costs, are attributed to inputs used. 
That which remains can be shared to equity, since the 'value produced' has already covered the 'value used' represented by all other remunerations (for labour, for debt capital, to suppliers of goods and services, to the state). Going further, it could be also included among values used those costs sustained by the company to reduce corporate environmental impact, that is to say costs for activities not strictly related to production, but connected to the wellbeing of personnel, such as activities forming part of the company's welfare programme.

It seems that this approach corresponds to the vision of the firm as a "community of interests" (Ardemani, 1968) and to Onida's thinking when he points out that to prosper i.e. to operate cost-effectively, the firm must strive not only to maximise profit, but also to ensure the "realisation of simultaneous maximums concerning salaries, dividends and self-financing" (Onida, 1968, p. 91). The firm therefore becomes a "centre of interests" (Onida, 1968 ) and it is this vision, albeit with a few differences, that it can be found in Masini (1977, 1988), Airoldi, Brunetti, Coda (Airoldi, Brunetti, \& Coda, 1994) and Capaldo (2013), to name only a few scholars of the Italian Academic tradition. In particular, it seems that in addition to aspects of social economics, Onida also includes explicitly ethical references in his studies (Onida, 1939:3). In the same line of thought, Masini sees the firm as an economic-social institution (Masini, 1977), occupying an intermediate level between civil societies and the civil consortium and, in his work "Lavoro e Risparmio" (translation Labour and Saving) (Masini, 1988), he develops a theory steeped in respect for values.

A multi-stakeholder vision of the firm is also offered by Cattaneo, who stresses that the performance of company activities is conditioned by the pursuit of the interests of those who work for the firm and those who appropriate the net results, but also by the pursuit of the interests of client companies and suppliers (Cattaneo, 1975). Should not be overlooked criticisms levelled at institutional theory by economic doctrine. Criticisms that are resolved by conferring upon the governing body the obligation and at the same time the privilege of a reductio ad unum process in relation to its own interests and those of all the stakeholders (Matacena, 1984; Rusconi, 1988; Lai, 2004). For Amaduzzi, the study of the firm must not stop simply at "double-entry book keeping", because behind accounting data are facts or economic phenomena that must be interpreted and without which the accounting results would have only a nominal function, which could lead to distortions and errors (Amaduzzi, 1969). It seems that despite his relevant contribution to the theory of the firm, it is neoclassical theory that remains at the forefront of Amaduzzi's mind.

In his definition of the firm, D'Ippolito, another illustrious pupil of Zappa, talks about "objectives" and "company subjects", developing the so-called systems theory of the firm and within the latter, the subjective aspect and therefore the involvement of the person (D'Ippolito, 1963). Coda (1988) clarifies the different dimensions of finalism with regard to the firm, namely the achievement of financial-economic and competitive results, plus consensus and cohesion with regard to suppliers. A "good" firm devotes equal strength and foresight to the simultaneous pursuit of all three dimensions, while a "bad" firm focuses exclusively on achieving one of the three dimensions, leading eventually to its own collapse. Giannessi also makes a significant contribution to literature on theories of the firm, with a concept of "value" that was relatively new in its day, introducing the concept of "relational value", namely value determined in relation to the reference context, destined to rearrange each phenomenon in the spatial and temporal order to which it belongs (Giannessi, 1990:279-280).

Lastly, the contributions by Gabrovec Mei, Marchini and Ferraris Franceschi offer further and significant stimuli to review the theories of the firm. They were some of the first female scholars to make original contributions to Business Administration, proposing innovative ideas in their revision of the male-oriented mainstream theory (Baldarelli, Del Baldo, 2018). Gabrovec Mei, in particular, clearly outlines the shift from a confrontational business model to a supportive model which, she believes, brings about a transition from a "culture of conflict to one of consensus" (Gabrovec Mei, 1997, p.562 and 565).

\section{Research Methodology and Results}

To comply with the paper aim a qualitative research method is applied (Patton, 2002). According to the relevant literature (Dumay, 2010; Jönsson \& Lukka, 2006) the analysis carried out considered various and progressive steps.

The first one concerns the choice of the selected keywords grounded on the relevant literature review. Secondly, the frequency of the keywords is measured on the NIBR-Network Italian Business Reporting- Integrated Reporting for SMEs- Implementation Guidance (2018) to deduct the novelties regarding the theory of the firm, that aforementioned guidelines suggest in voluntary implementation of IR (Flower, 2015). Finally, the results are supported by an in-depth interview to a member that took part to the committee that drew up the Guidelines. The interview questions and length were defined following main literature (Bovens, 2007; Dumay, 2010), and the 
interview protocol was formed to mitigate the researchers bias. Thus the "right" person in the organisation has been selected as an informant (Huber \& Power, 1985).

The second step of research is based on content analysis, "a technique for gathering data that consists of codifying qualitative information in anecdotal and literary form into categories in order to derive quantitative scales of varying levels of complexity" (Abbott \& Monsen, 1979, p. 504; Guthrie \& Abeysekera, 2006). The frequency of these keywords was measured inside of the NIBR Guidelines for SMES.

The relevance of the latter to this paper aim is due to two reasons. One the one hand, the Italian economic system is mainly based on SMES as evidenced by the data of the national statistics body: "the small and medium-sized enterprises (SMEs), which distinguish the structure of our production system, dominate the scenario of local economies producing at least $80 \%$ of the added value in 4 municipalities out of 5" (ISTAT, 2019 p. 6). One the other hand, the recommendations are very important, because will be used by the SMEs to prepare their Integrated Reporting (IR). NIBR Guidelines had a 3 years gestation before the final enactment and the third step of research has the objective to understand the strategic orientation and motivations, that underlined the entire process of making IR guidelines for SMEs (Bebbington et al, 2017).

Figures 1and 2 and Table 1 show some relevant data to support the Authors' decision to focus on SMEs. Every data have been extracted from ISTAT (Official Italian National Institute of Statistics). The last data available are related to year 2017.

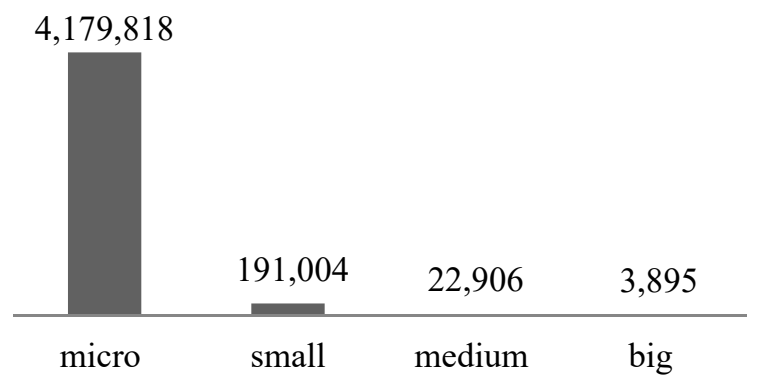

Figure 1. Number of Italian enterprise divided for size class

Source. Extrated data by the Authors from Istat data base 14 April 2020

Table 1. Size class and number of Italian enterprises

\begin{tabular}{|c|c|c|c|c|}
\hline & Micro & Small & Medium & Big \\
\hline Size class (per number of workers) & $0-9$ & $10-49$ & $50-249$ & 250 and more \\
\hline Number of enterprises operating & $4,179,818$ & 191,004 & 22,906 & 3,895 \\
\hline \multicolumn{5}{|c|}{$\begin{array}{r}\text { medium } \\
1 \% \mathrm{big} \\
0 \%\end{array}$} \\
\hline
\end{tabular}

Figure 2. Percentage composition of Italian production context 
Furthermore, the analysis referring to SMEs is relevant because the latter are the backbone not only of the Italian economy but also of the European one, where they represent $99 \%$ of all businesses. Over the past five years, European SMEs as a whole have given around $85 \%$ of new jobs and provided two thirds of total private sector employment, as EU data show (EC, 2020). Thus the European Commission considers SMEs pivotal in ensuring economic growth, innovation, job creation, and social integration in the EU (EC, 2020).

The interviews had been started on January 2020 and ended on March 2020. They involved six open questions showed in the Table 2.

Table 2. Main questions

\begin{tabular}{ll}
\hline No. & Questions \\
\hline 1 & What keywords do you think can be associated to describe the process of implementation of the IR? \\
2 & What keywords would you associate with the preparation of the statutory financial statements? \\
3 & Has the implementation of the IR led to certain changes in the company behaviour? \\
4 & Which changes has been detected? (e.g. KPIs, KRIs, surrounding environment, number or intensity of the relationship with internal \\
& $\begin{array}{l}\text { and external stakeholder) } \\
\text { Do you think that the female role has influenced the choice and speed of the integrated reporting implementation process? }\end{array}$ \\
& $\begin{array}{l}\text { The label "business model" is part of the old theoretical framework and is one of the pillars that keep it anchored to the old view of the } \\
\text { business. Do you think the "integrated business model" could be associated with a new business theory? }\end{array}$
\end{tabular}

The interviews lasted on average 45 minutes each. The details of them are summarize in the Table 3.

To avoid researchers' bias and decrease the subjectiveness of data analysis, the answers were transcribed and then investigated by the four authors separately (Dumay, 2010). Afterwards, the personal interpretations were blended and the discussion of the results presented.

Table 3. Interview details

\begin{tabular}{ll}
\hline Role of the interviewee & Date of the interview \\
\hline Associate Professor and Member of NIBR Committee & January 2020 \\
& February 2020 \\
& March 2020 \\
\hline
\end{tabular}

\subsection{The Results of Empirical Research}

The literature review showed various and relevant keywords. The keywords are divided in two areas referable respectively to the traditional and new theory of the firm. The first group includes i) profitability, ii) financial, iii) shareholders, iv) investors, v) capital/s, vi) contract/s/ual, vii) business/es, while the second one involves i) skills, ii) social, iii) stakeholder/s, iv) responsibility, v) relation $/ \mathrm{s} / \mathrm{ship} / \mathrm{s}$, vi) community/es, vii) people. Some of these keywords are the opposite in the two areas.

The content analysis allowed to measure the frequency of the keywords into the NIBR Guideline as showed into the Figure 3. 


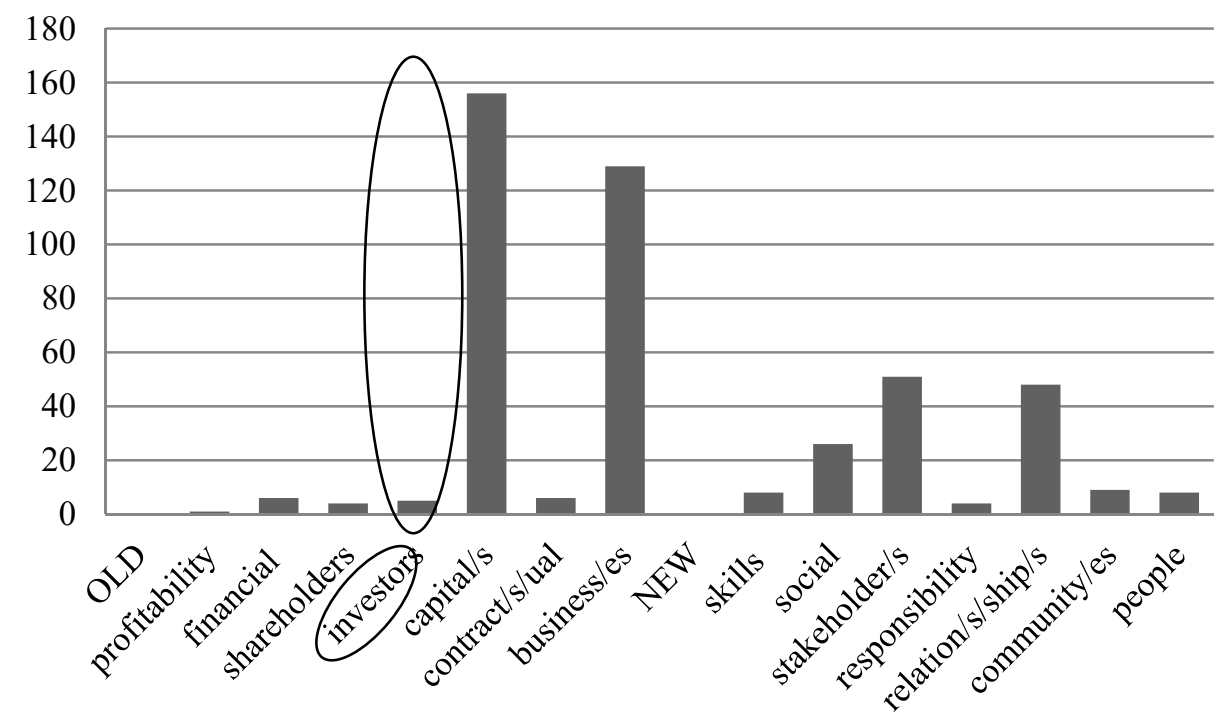

Figure 3. Frequency of old and new keywords

Before to express a comment, it will be considered not so relevant the histogram referred to Capital/s, because it can be considered along with the new words inside of the IR. Moreover, the traditional keywords create a frequency that is evident from the Figure 3. The frequency of the new terms into the NIBR Guideline is not very high, but are represented relevant keywords such as social, stakeholder and relationships.

As underlined before, to give an empirical support to the key words drew out of literature review, an in-depth interview to a member of NBRI was carried out. The interview results show that the process of IR implementation will be inspired by various stimuli. According to the NIBR Committee Member:

"[T] he implementation process of IR can be summarize through some key words such as integration, business model, communication, users, stakeholders, integrated thinking, SMEs, entrepreneur,

Focusingulti-dimensionglite" " implementation of the Guidelines process, some suggestions are derived from the second question of the interview scheme. The Guidelines seem consistent with the results of the literature review. The interviewee tells:

"[I]n my opinion the traditional key words underpinning to the financial statement are financial reporting, financial / economic performance and investors".

Focusing on the matter it can be considered that there is a certain coherence between literature and stimuli that led to the elaboration of the guidelines. The IR implementing has stimulated various changes in companies.

\footnotetext{
" $[W]$ ith reference to the companies that participated in the working table, we have noticed some changes such as the reassessment of the circulation of the wealth within and outside the company, a rethink of both the business model and the way it is shared and communicated externally".
}

Furthermore the implementation of the IR aims to push companies to highlight some KPIs, KRIs that were not previously monitored (e.g. human resources-training hours, gender activities). As regards the set of indicators suggested to the SMEs, which are the most rooted companies in the territory, the guidelines do not define a rigid list, but propose an grid open. The interviewee says:

\section{"[T] he Guidelines suggest some KPIs, and underline the importance of the disclosure indicators more closely connected to the territory"}

No major changes were noted in relation to the stakeholders represented in the IR. The SMES guidelines place great emphasis on the financial aspects so the main stakeholders are banks, lenders, tax authorities. There is no great space for the others.

"[E]ven if the IR aims to exploit various types of capital, the emphasis on the financial aspects also remains in the guidelines. (...) The SMEs participating in the working table have pushed for a broader representation of their value and said: "We are beautiful companies, we must look for a tool that also shows other assets such as the intangibles ones (e.g. patents)". 
In the process of implementing the IR, the contribution of women has been decisive in at least a couple of situations. There was a very constructive contribution from two female practitioners because they showed a strong sensitivity in emphasizing non-financial capital. The interviewee points out:

"[I]n one case, the sensitivity of an external consultant and a CFO was successful (man and woman) because they emphasized the integrated vision of the business model underpinning the IR. (...) We have done everything to spread the IR by placing a lot of emphasis on non-financial capital, but the intervention has so far been partial".

The word "business model" could be linked to the old theoretical framework. One of the most important aspects to investigate in order to respect the paper aim is whether the integrated model could introduce a new business theory.

"[T] he business model is the main aspect of IR. Companies are required to describe it, but it does not necessarily become an instrument of change even if it is an opportunity to rethink and deepen the business model. The idea is that it becomes an important element that companies are considering for the listing on the stock exchange".

From the last answers a contradiction is drawn because the IR focus seems to be only on the traditional representation. This assertion requires further researches to be confirmed or not.

\section{Discussion and Conclusion}

The insights that derive from this study of the theoretical framework of IR and after the empirical analysis are that no strong signals emerge that encourage a truly different, new (holistic and integrated) conception of the firm. This conclusion answers to the research question: "Could the theory of the firm, that is underlined by IR, open to innovation by way of the Business Administration perspective?"

Contractual theories (Speziale, 2018), ascribable to neoclassical theories (agency theory, shareholder theory, instrumental and normative stakeholder theory), "justify" the goal of maximisation of short-term profit and user (shareholder) interests, undermining the ability of innovative corporate communication tools like IR to go beyond a weak sustainability paradigm that puts financial stakeholders first (Alexander \& Blum, 2016, Brown \& Dillard, 2014, Flower, 2015, Reuter \& Messner, 2015; Stubbs \& Higgins, 2015; Tweedie \& Martinov-Bennie, 2015).

But a few encouraging signals, albeit weak ones, ought to be acknowledged. In other words, it seems to us that there is now an acceptance of the actual concept of integrated reporting (consider that the very term "integrated report" was unheard of in Accounting until the start of the century) and widespread awareness of the need to redefine the notion of value and its distribution. However, in general, it can be noted that the idea underpinning integrated reporting appears to underline the value of other "capitals" that are considered only according to their contribution to the wealth of the firms. Contrary to this conclusion, encouraging signs have come from this paper thanks to the content analysis which has shown a fair interest in concepts that underlie a new vision of business action, as shown in Tab. 4

Table 4. New and old keywords representative of the theory of the firm

\begin{tabular}{lccc}
\hline $\begin{array}{c}\text { Old key words underpinning the } \\
\text { financial statement }\end{array}$ & $\begin{array}{c}\text { Frequency in } \\
\text { NIBR Guidelines }\end{array}$ & \multicolumn{1}{c}{$\begin{array}{c}\text { New key words } \\
\text { underpinning the IR }\end{array}$} & $\begin{array}{c}\text { Frequency in } \\
\text { NIBR Guidelines }\end{array}$ \\
\hline profitability & 1 & skills & 8 \\
financial & 6 & social & 51 \\
shareholders & 4 & rtakeholder/s, & 48 \\
investors & 5 & responsibility & 9 \\
capital/s & 156 & community/es & 8 \\
contract/s/ual & 6 & people & 4 \\
business/es & 129 & &
\end{tabular}

In this context, significant progress towards an effective change in the theory of the firm might be made if the systemic view, so dear to the Italian Business Administration tradition (which considers the firm a 
socio-economic institution destined to last, construed firstly as a community of people).

Only in this way IR can be a genuine tool for sustainability reporting that can reconcile the different logics of valuation or orders of worth.

In this way, it can help integrate the change heralded by the new frontiers of reporting, of which the integrated report is both an expression and a synthesis. In other words, it is not so much that a "new" theory of the firm is to be drawn from integrated reporting, but that a "new" theory of the firm must form the basis of the integrated report. Otherwise, far from being a tool for representing "integral value" (Sorci, 2006), it will amount to nothing more than "greenwashing" (Mahoney, Thorne, Cecil \& La Gore, 2013).

Focusing on Italy, consideration needs to be given to a significant criticism, precisely whether, and in the event how, the subject dealt with in this paper is present in prevailing research literature and what effects might ensue from a review of the theory of the firm underpinning integrated reporting.

According the literature review, in Italy the theoretical construct of Business Administration presented some elements that can be defined a review of mainstream theory, through the introduction of further elements of analysis in addition to traditional ones (Onida, 1968; Viganò, 2013; Canziani, 2013). Nevertheless, the empirical research of this paper as well the most recent Business Administration literature review showed that despite all the premises the results are still quite disappointing.

On the one hand, the guidelines that SMEs will follow to draw up the IR on a voluntary basis, do not seem to make a real contribution to the designs of a new business theory. On the other hand, in recent years there has been the development of a process that has led Business Administration to "narrow" its field of inquiry and base the latter on methods, for example mathematical or statistical, which have already been harshly criticised in other disciplines.

This paper contributes to the existing literature by offering an in-depth analysis of the link between theoretical aspects of business theory, current evolutionary trends and their application in the real world. The results of the paper can offer interesting insights to scholars and accounting professional bodies that must lead accountability strategies and tools. The limitations of this work are that the latter focused only on NIBR Guidelines for SMES and some research cases are required.

Further steps of the research will be to compare the implementation of the NIBR Guidelines in different countries and extend the empirical phase by providing a longitudinal study.

\section{References}

Abbot, W. F., \& Monsen, J. R. (1979). On the Measurement of Corporate Social Responsibility: Self-Reported Disclosures as a Method of Measuring Corporate Social Involvement. Academy of Management Journal, 22(3), 501-515. https://doi.org/10.2307/255740

Adams, C. A. (2015). The international integrated reporting council: A call to action. Critical Perspectives on Accounting, 27, 23-28. https//doi.org/10.1016/j.cpa.2014.07.001

Airoldi, G., Brunetti, G., \& Coda, V. (1994). Economia aziendale. Milano: Il Mulino.

Alexander, D., \& Blum, V. (2016). Ecological economics: A Luhmannian analysis of integrated reporting. Ecological Economics, 129, 241-251. https//doi.org/10.1016/j.ecolecon.2016.06.020

Amaduzzi, A. (1969). L'azienda nel suo sistema e nell'ordine delle sue rilevazioni. Torino: Unione Tipografico-Editrice Torinese.

Ardemani, E. (1968). L'evoluzione del concetto d'impresa e dei sistemi contabili in Italia. Rivista dei Dottori Commercialisti, 3 .

Baldarelli, M. G., \& Del Baldo, M. (2018). Social Accounting in Italy: The Pioneering Contribution of Women Scholars. In P. Paoloni, \& R. Lombardi (Eds.), Gender Issues in Business and Economics. Springer Proceedings in Business and Economics. Cham-Switzerland: Springer International Publishing. https://doi.org/10.1007/978-3-319-65193-4_1

Baldarelli, M. G., Del Baldo, M., \& Vignini, S. (2019). The first women accounting masters in Italy: between tradition and innovation. Accounting History Review, 29(1), 1-40, https://doi.org/10.1080/21552851.2019.1610467

Bebbington, J., Russell, S., \& Thomson, I. (2017). Accounting and sustainable development: Reflections and propositions, Critical Perspectives on Accounting, 48, 21-34. https://doi.org/10.1016/j.cpa.2017.06.002 
Bovens, M. (2007). Analysing and assessing accountability: A conceptual framework 1. European Law Journal, 13(4), 447-468. https://doi.org/10.1111/j.1468-0386.2007.00378.x

Brown, J., \& Dillard, J. (2014). Integrated reporting: On the need for broadening out and opening up. Accounting, Auditing \& Accountability Journal, 27(7), 1120-1156. https://doi.org/10.1108/AAAJ-04-2013-1313

Busco, C., Frigo, M. L., Quattrone, P., \& Riccaboni, A. (2013). Towards integrated reporting: concepts, elements and principles. Integrated Reporting. Cham: Springer.

Camilleri, M. A. (2018). Theoretical Insights on Integrated Reporting: The Inclusion of Non-Financial Capitals in Corporate Disclosures. Corporate Communications: An International Journal, 1-22. https//doi.org/10.1108/CCIJ-01-2018-0016

Campanini, C. (1982). Economia e Tecnica dell'impresa alberghiera. Lezioni. Bologna: CLUEB

Campra, M., Esposito, P., \& Lombardi, R. (2020). The engagement of stakeholders in nonfinancial reporting: New information-pressure, stimuli, inertia, under short-termism in the banking industry. Corporate Social Responsibility and Environmental Management. https://doi.org/10.1002/csr.1896.

Canziani, A. (2013). Accounting and "Economia Aziendale" in Italy, 1911 Afterward. Accounting and business economics. Insight from national traditions, New York-London: Routledge.

Capaldo, P. (2010). L'economia aziendale oggi. Milano:Giuffrè Editore.

Capaldo, P. (2013). L'azienda. Centro di produzione. Milano:Giuffrè.

Cattaneo, M. (1975). Economia delle aziende di produzione. Milano: ETAS Libri.

Chapman, C. S., Cooper, D. J., \& Miller, P. (Eds.) (2009). Accounting, organizations and institutions: Essays in honor of Anthony Hopwood. New York: Oxford University Press.

Coda, V. (1988). L'orientamento strategico dell'impresa. Roma: UTET.

De Villiers, C., Venter, E.R., \& Hsiao, P. C. K. (2017). Integrated reporting: background, measurement issues, approaches and an agenda for future research. Accounting \& Finance, 57(4), 937-959. https//doi.org/10.1111/acfi.12246

Deegan, C. (2002). The legitimizing effect of social and environmental disclosures: A theoretical foundation. Accounting, Auditing \& Accountability Journal, $282-311$. https//doi.org/10.1108/09513570210435852

D'Ippolito, T. (1963). Istituzioni di amministrazione aziendale (5th ed.). Palermo-Roma: Abbaco.

Donaldson, T., \& Preston, L. E. (1995). The stakeholder theory of the corporation: Concepts, evidence, and implications. Academy of Management Review, 20(1), 65-91. https://doi.org/10.4236/ajibm.2014.4120824

Dumay, J. (2010). A critical reflective discourse of an interventionist research project. Qualitative Research in Accounting \& Management, 7(1), 46-70. https://doi.org/10.1108/11766091011034271

Dumay, J., \& Dai, T. (2016). Integrated thinking as a cultural control? Meditari Accountancy Research, 25(4), 574-604. https://doi.org/10.1108/MEDAR-07-2016-0067.

Dumay, J., \& Zambon, S. (2016). A critical reflection on the future of intellectual capital: From reporting to disclosure. Journal of Intellectual Capital, 17, 168-184. https//doi.org/10.1108/JIC-08-2015-0072

Dumay, J., Bernardi, C., Guthrie, J., \& Demartini, P. (2016). Integrated reporting: A structured literature review. Accounting Forum, 40(3), 166-185. https://doi.org/10.1016/j.accfor.2016.06.001

Dumay, J., La Torre, M., \& Farneti, F. (2019). Developing trust through stewardship: Implications for intellectual capital, integrated reporting, and the EU Directive 2014/95/EU. Journal of Intellectual Capital, 20(1), 11-39. https://doi.org/10.1108/JIC-06-2018-0097

Eccles, R. G., \& Krzus, M. P. (2010). One Report. Integrated Reporting for a sustainable Strategy. New Jersey and Canada: Wiley.

EU. (2014). The European Parliament mandate Directive 2014/95/EU on nonfinancial reporting. Retrieved from https://eur-lex.europa.eu/legal-content/EN/TXT/? uri= CELEX\%3A32014 L0095

Evan, W. M., \& Freeman, R. E. (1988). A Stakeholder Theory of the Modern Corporation: Kantian Capitalism. In T. Beauchamp, \& N. Bowie (Eds.). Ethical Theory and Business. Englewood Cliffs, NJ: Prentice Hall.

Ferraris, F. R. (1998). Che cosa ci unisce, che cosa ci divide dagli economisti generali. Rivista Italiana di 
Ragioneria e di Economia aziendale, 3.

Flower, J. (2015). The international integrated reporting council: A story of failure. Critical Perspectives on Accounting, 27, 1-17. https//doi.org/10.1016/j.cpa.2014.07.002

Freeman, R. E. (1984). Strategic Management: A Stakeholder Approach. Pitman Publishing, Boston, MA.

Freeman, R. E., \& Reed, D. L. (1983). Stockholders and stakeholders: A new perspective on corporate governance. California Management Review, 25(3), 88-106. https://www.jstor.org/stable/41165013

Freeman, R. E., Harrison, J. S., Wicks, A. C., Parmar, B. L., \& De Colle, S. (2010). Stakeholder Theory: The State of the Art. Cambridge: Cambridge University Press.

Gabrovec Mei, O. (1984). Il valore aggiunto dell 'impresa. Trieste: Libreria Goliardica.

Gabrovec Mei, O. (1997). L'analisi delle performance nei modelli solidali d'impresa. In AA.VV. Scritti di Economia aziendale in memoria di Raffaele D'Oriano. Padova: CEDAM.

Giannessi, E. (1990). Appunti di Economia aziendale. ( 1st ed.). Ristampa, Pisa: Pacini.

Gray, R. H., Kouhy, R., \& Lavers, S. (1995). Corporate social and environmental reporting: A review of the literature and a longitudinal study of UK disclosure. Accounting, Auditing \& Accountability Journal, 8(2), 47-77. https://doi.org/10.1108/09513579510146996

Guarini, E., Magli, F., \& Nobolo, A. (2013). From Accounting to" Economia Aziendale": Innovation in the Thought of Gino Zappa (Italy, 1879-1960). Rirea

Guthrie, J., \& Abeysekera, I. (2006). Content analysis of social, environmental reporting: What is new? Journal of Human Resource Costing \& Accounting, 10(2), 114-126. https://doi.org/10.1108/14013380610703120

Haller, A., \& Van Staden, C. (2014). The value added statement - an appropriate instrument for integrated reporting. Accounting, Auditing \& Accountability Journal, 27(7), 1190-1216. https://doi.org/10.1108/AAAJ-04-2013

Huber, G. P., \& Power, D. J. (1985). Retrospective reports of strategic-level managers: Guidelines for increasing their accuracy. Strategic Management Journal, 6. https://doi.org/10.1002/smj.4250060206

IIRC. (2013). The International IR Framework, The International Integrated Reporting Council, London. Retrieved from http://www.theiirc.org/wp-content/uploads/

ISTAT. (2019). Risultati economici delle imprese a livello territoriale - anno 2016 (Economic results of business at a territorial level - Year 2016). Retrieved from https://www.istat.it/it/files//2019/06/Risultati-economici-delle-imprese-a-livello-territoriale.pdf

Jensen J. C., \& Berg, N.(2012). Determinants of Traditional Sustainability Reporting Versus Integrated Reporting. An Institutionalist Approach. Business Strategy and the Environment, 21(5), 299-316. https://doi.org/10.1002/bse.740

Jönsson, S., \& Lukka, K. (2006). There and back again: doing interventionist research in management accounting. Handbooks of Management Accounting Research, 1, 373-397. https://doi.org/10.1016/S1751-3243(06)01015-7

La Torre, M., Sabelfeld, S., Blomkvist, M., Tarquinio, L., \& Dumay, J. (2018). Harmonising non-financial reporting regulation in Europe: Practical forces and projections for future research, Meditari Accountancy Research, 26(4), 598-621. https://doi.org/10.1108/MEDAR-02-2018-0290

Lai, A. (2004). Paradigmi interpretativi dell'impresa contemporanea. Teorie istituzionali e logiche contrattuali. Milano: Angeli.

Magistro, A. (1989). Economia aziendale,microeconomia e macroeconomia. Nuovi orientamenti di studio nel rapporto micro-macro. Roma: Edizioni Kappa.

Mahoney, L. S. Thorne, L., Cecil, L., \& La Gore, W. (2013). A research note on standalone corporate social responsibility reports: Signalling or greenwashing? Critical Perspectives on Accounting, 24(4/5), 350-359. https://doi.org/10.1016/j.cpa.2012.09.008

Masini, C. (1977). Impresa, azienda di produzione e ambiente. Rivista internazionale di Scienze Economiche, 5-6.

Masini, C. (1988). Lavoro e Risparmio. Torino: UTET.

Matacena, A. (1984). Impresa e Ambiente, verso un bilancio "societale". Bologna: CLUEB. 
Mattessich, R. (2013). Accounting Theories of the First Half of the Twentieth Century: The Genesis of an Academic Discipline. In Biondi Y. \& Zambon S. (Eds.), Accounting and Business Economics ( pp. 3-38).

Maunders, K. T. (1985). The Decision Relevance of Value Added Reports. In Choi, F. E., \& Mueller, G. G. (Eds.), Frontiers of International Accounting: An Anthology (pp. 225-245). Ann Arbor, MI: UMI Research Press.

Mio, C. (2016). Integrated Reporting: A New Accounting Disclosure. Palgrave.

Monciardini, D., \& Conaldi, G. (2019). The European regulation of corporate social responsibility: The role of beneficiaries' intermediaries. Regulation \& Governance, 13(2), 240-259. https://doi.org/10.1111/rego.12248

Mouritsen, J., Bukh, P. N., \& Marr, B. (2005). A Reporting Perspective on Intellectual Capital. In B. Marr (Ed.), Perspectives on Intellectual Capital (pp. 69-81). Pergamon Press.

Onida, P. (1939). Le dimensioni del capitale di impresa. Concentrazioni, trasformazioni, variazioni di capitale. Milano: Giuffrè.

Onida, P. (1968). Economia d'azienda. Torino: Utet.

Parker, L. D. (2005). Social and environmental accounting research. A view from the commentary box. Accounting, Auditing \& Accountability Journal, $18(6), \quad 824-860$. https://doi.org/10.1108/09513570510627739

Paternostro, S. (2012) L'accountability nell'azienda integrale. Prime riflessioni sulla valenza informativa del bilancio integrato Collana Quaderni di ricerca economico-aziendali: teoria e casi/5, Roma: Aracne.

Perego, P., Kennedy, S., \& Whiteman, G. (2016). A lot of icing but little cake? Taking integrated reporting forward. Journal of Cleaner Production, 136, 53-64. https://doi.org/10.1016/j.jclepro.2016.01.106

Pollifroni, M. (2012). Environmental sustainability and social responsibility: a theoretical proposal for an accounting evaluation. Economia Aziendale Online, 2(4), 345-354. http://dx.doi.org/10.13132/2038-5498/2.4.345-354

Pollifroni, M. (2017). L'Etica Aziendale nei Processi di Globalizzazione dei Mercati. Paradigmi, Determinanti, Valutazioni (Vol. 71). Giappichelli, Torino.

Ponzanelli, G. (1975). Lezioni di Ragioneria generale. Siena.

Reuter, M., \& Messner, M. (2015). Lobbying on the integrated reporting framework: An analysis of comment letters to the 2011 discussion paper of the IIRC. Accounting, Auditing \& Accountability Journal, 28(3), 365-402. https://doi.org/10.1108/AAAJ-03-2013-1289

Roberts, R. W. (1992). Determinants of corporate social responsibility disclosure: An application of stakeholder theory. Accounting, Organizations and Society, 17(6), 595-612.

Rowbottom, N., \& Locke, J. (2016). The emergence of $<\mathrm{IR}>$. Accounting and business Research, 46(1), 83-115. https://doi.org/10.1080/00014788.2015.1029867

Rusconi, G. (1988). Il bilancio sociale dell'impresa. Problemi e prospettive. Milano: Giuffrè.

Rusconi, G. (2019). Ethical Firm System and Stakeholder Management Theories: A Possible Convergence. European Management Review, 16, 147-166. https://doi.org/10.1111/emre.12162

Signori, S., \& Rusconi G. (2009). Ethical Thinking in Traditional Italian Economia Aziendale and the Stakeholder Management Theory: The Search for Possible Interactions. Journal of Business Ethics, 89(3) 303-318. https://doi.org/10.1007/s10551-010-0391-7

Simpson, S., Fischer, B. D., \& Rhode, M. (2013). The conscious capitalism philosophy pay off: A qualitative and financial analysis of conscious capitalism corporations. Journal of Leadership, Accountability \& Ethics, 10(4), 19-29.

Smith, S. S. (2016). Integrated reporting \& the future of auditing. Journal of Accounting and Finance, 16(1), 140-145.

Sorci, C. (2006). Responsabilità e sviluppo integrale delle aziende. Appunti per un dibattito sulla cultura aziendale, 85-94.

Speziale, M. T. (2018). Theoretical Perspectives on Purposes and Users of Integrated Repoting: A Literature Review. In S. O. Idowu \& M. Del Baldo (Eds.), Integrated Reporting: Antecedents, Perspectives/Outlooks for Organisations and Stakeholders (pp. 27-75). Heidelberg: Springer International Publishing Switzerland.

Stubbs, W., \& Higgins, C. (2015). Stakeholders' perspectives on the role of regulatory reform in integrated 
reporting. Journal of Business Ethics. https://doi.org/10.1007/s10551-015-2954-0

Thomson, I. (2015). But does sustainability need capitalism or an integrated report: A commentary on "The International Integrated Reporting Council: A story of failure" by Flower. Critical Perspectives on Accounting, 27, 18-22. https://doi.org/10.1016/j.cpa.2014.07.003

Tweedie, D., \& Martinov-Bennie, N. (2015). Entitlements and time: Integrated reporting's double-edged agenda. Social and Environmental Accountability Journal, 35(1) 49-61. https://doi.org/10.1080/0969160X.2015.1007466

Van Bommel, K. (2014). Towards a legitimate compromise?: An exploration of integrated reporting in the Netherlands. Accounting, Auditing \& Accountability Journal, 27(7), 1157-1189. http://dx.doi.org/10.1108/AAAJ-04-2013-1309

Velte, P., \& Stawinoga, M. (2017), Integrated reporting: The current state of empirical research, limitations and future research implications. Journal of Management Control. https://doi.org/10.1007/s00187-016-0235-4.

Veltri, S. Bronzetti G., \& Sicoli, G. (2011). Reporting intellectual capital in health care organizations: specifics, lessons learned and future research perspectives. J. Health Care Finance. 38(2), 79-96.

Viganò, E. (2013). Accounting and business economics traditions in Italy. In Biondi Y., \& Zambon S. (Eds.), Accounting and Business Economics (pp. 422-441).

Zappa, G. (1957). Le produzioni nell'economia delle imprese. Milano: Giuffrè.

Zappa, G. (1962). L'economia delle aziende di consumo. Milano: Giuffrè.

\section{Note}

Note 1. Implementation of Directive 2014/95/EU of the European Parliament and of the Council of 22 October 2014 amending Directive 2013/34/EU as regards disclosure of non-financial information.

\section{Copyrights}

Copyright for this article is retained by the author(s), with first publication rights granted to the journal.

This is an open-access article distributed under the terms and conditions of the Creative Commons Attribution license (http://creativecommons.org/licenses/by/4.0/). 